\title{
Phytochemical Composition and Antimicrobial Properties of Burdock (Arctium lappa L.) Roots Extracts
}

\author{
Nadezhda Petkova ${ }^{1, *}{ }^{(\mathbb{D})}$, Ivanka Hambarlyiska ${ }^{1}$, Yulian Tumbarski ${ }^{2}{ }^{(\mathbb{D})}$, Radka Vrancheva ${ }^{3(\mathbb{D})}$, Miglena \\ Raeva ${ }^{1}$, Ivan Ivanov 1 (iD \\ 1 Department of Organic Chemistry and Inorganic Chemistry, University of Food Technologies, 26 Maritza Blvd., 4002 \\ Plovdiv, Bulgaria, petkovanadejda@abv.bg (N.P.); vanya.hambarliyska@gmail.com (V.H.); naskosaew@abv.bg (M.R.); \\ ivanov_ivan.1979@yahoo.com (I.I.); \\ 2 Department of Microbiology, University of Food Technologies, 26 Maritza Blvd., 4002, Plovdiv, Bulgaria; \\ tumbarski@abv.bg (Y.T.); \\ 3 Department of Analytic and Physicochemistry, University of Food Technologies, 26 Maritza Blvd., 4002, Plovdiv, \\ Bulgaria; radka_vrancheva@yahoo.com (R.V.); \\ * Correspondence: petkovanadejda@abv.bg (N.P);
}

Scopus Author ID 56507003400

Received: 2.06.2021; Revised: 5.07.2021; Accepted: 10.07.2021; Published: 8.08.2021

\begin{abstract}
Burdock (Arctium lappa L.) roots were used as a medicinal plant or vegetable worldwide. The research aimed to obtain different fractions by sequential extraction (hexane, chloroform, ethyl acetate water) of burdock roots and to evaluate phytochemical compounds in them. Antioxidant and antimicrobial properties of nonpolar fractions were evaluated. Ethyl acetate fraction contained the highest total phenolics, total flavonoids, and derivatives of caffeic acids. Phenolic acids (mainly chlorogenic, caffeic acid, and p-coumaric acids) were detected only in the ethyl acetate fraction, while in the hexane fraction was found only triterpenes. Due to the high polyphenol content, the ethyl acetate fraction demonstrated the highest antioxidant activity. Three fractions revealed antimicrobial activity against Salmonella sp., Escherichia coli, Listeria monocytogenes, Pseudomonas aeruginosa, Proteus vulgaris, Staphylococcus aureus, Bacillus cereus, and Candida albicans. The lowest minimum inhibitory concentration ( $>1 \mathrm{mg} / \mathrm{ml}$ ) showed an ethyl acetate fraction against Pseudomonas aeruginosa and Bacillus cereus. From the water fraction was isolated inulin-type fructan with a degree of polymerization 20-24 with promising functional properties. This study showed the potential application of burdock root fractions as a rich source of phytochemicals with antimicrobial, antioxidant activities, and potential prebiotic effect due to the $7 \mathrm{~g} / 100 \mathrm{~g}$ inulin content in them.
\end{abstract}

Keywords: burdock, inulin, phenolic compounds, antimicrobial activity

(C) 2021 by the authors. This article is an open-access article distributed under the terms and conditions of the Creative Commons Attribution (CC BY) license (https://creativecommons.org/licenses/by/4.0/).

\section{Introduction}

Arctium lappa L. (A. lappa L.), commonly known as burdock or gobo (in Japan), bardane in (France and Italy), is a medicinal plant from Asteraceae family that originates from Asia and Europe and it is widespread and adapted for cultivation in different climates and continents [1-3]. The vegetation period varies from 8 to 12 months as its yield can reach from 8 to $40 \mathrm{t} / \mathrm{ha}$. Moreover, it has been widely consumed as a vegetable in East Asia for centuries. It has a cylindrical shape $(45-50 \mathrm{~cm}$ long and $3-6 \mathrm{~cm}$ in diameter), thin brown skin, and the inner part is from white to yellowish-white [1]. In European countries, burdock root is consumed as an herbal infusion, decoction, or tincture [4]. Extracts prepared from the different parts of the burdock plant possesses various biological activities and pharmacological 
functions, including antioxidant, anti-inflammatory, anticancer, antidiabetic, antimicrobial, antiviral effects, anti-allergic, antiulcer, anti-tubercular, anti-sterility, angiostrongyliasis, gastroprotective, anti-esoteric, hepatoprotective, anti-cytotoxic effect and antiacne [4-14]. The water extract of Arctium lappa L. roots enhanced chondrogenic medium-induced chondrogenic differentiation [13], improved abdominal obesity and sex hormones in elderly women with metabolic syndrome [15], and demonstrated aphrodisiac effect in experimental rats [16]. The root extracts also demonstrated gastroprotective activity and neuroprotective effects due to several monocaffeoylquinic acids and dicaffeoylquinic acids [14]. The main biologically active substances in burdock roots comprise volatile compounds, tannin, $\beta$-eudesmol, caffeic acid, chlorogenic acid, inulin, trachelogenin, sitosterol- $\beta$-D-glucopyranoside, lappaol, terpenes, polyynes, arctiin, arctigenin, and diarctigenin [14,17-22].

A. lappa L. roots have been received increasing interest, not only because of phenolic compounds but also for the content of polysaccharides with various health-beneficial properties [1,6]. Its roots contain pectic polysaccharides (993 mg uronic acid /100 g), as 53.9\% of them characterized as low methoxyl pectin with a degree esterification 38\% [23]. Anti-inflammatory activity of alkali-soluble polysaccharides from Arctium lappa L. was also demonstrated [24], while citric acid extracted pectin showed anti-constipation activity [25].

Literature deals mostly with the extraction methods, composition changes, structure identification, prebiotic effects, antitussive and anti-colitic activity of fructan from burdock [7, $17,18,26]$. Moreover, it was reported for isolation of linear $\beta$-1,2-glucofructan from A. lappa roots with a degree of polymerization $18-19\left(\mathrm{M}_{\mathrm{w}}=2.95 \mathrm{kDa}\right)$ with an antitussive effect and immunomodulatory activity, comparable with zymosan [18, 22]. Fuchigami et al. (1990) fractioned from the roots of Japanese edible burdock inulin with a molecular weight of about $5 \mathrm{kDa}$ [23]. Lei [27] elucidated the fructan structure that comprised of D-Fruf and -D-Glcp in the molar ratio of 14:1. Liu et al. (2014) isolated inulin-type fructan from the roots of Arctium lappa with fructose and glucose in the ratio of 13.0:1.0, and with an average molecular weight of $4600 \mathrm{Da}$, possesses in vitro and in vivo antioxidant activity [7]. Prebiotic ingredients from burdock roots were isolated without organic solvents and wastes [18]. The accelerated method as ultrasonic and microwave irradiation and pressure-liquid extraction was performed to optimize fructan extraction from A. lappa roots, and inulin content was measured in the extracts $[8,20,28]$. Until now, the characteristics of inulin from burdock water fraction isolated by microwave irradiation were absent. Moreover, the fractional extraction of bioactive compounds using solvents with different polarities was not investigated in detail.

The aim of the current study was to obtain different fractions by sequential extraction of burdock roots and to evaluate phytochemical compounds in them. In addition, antioxidant and antimicrobial activities of nonpolar fractions were also of interest.

\section{Materials and Methods}

\subsection{Materials.}

The dried roots of burdock (Radix Arctii Lappae) produced by ALIN Company (Alino village, Samokov, Bulgaria) were bought from the local drugstore in Plovdiv, Bulgaria. The roots were finely ground in a laboratory homogenizer and sieved through $0.5 \mathrm{~mm}$. All reagents were analytical grade (Sigma-Aldrich Chemie GmbH, Darmstadt, Germany). 


\subsection{Moisture content.}

The moisture content of roots was determined according to the AOAC method [29].

\subsection{Sequential solvent extraction and fructan isolation by microwave extraction.}

Extraction using solvents with different polarities was performed. Powdered burdock roots $(100 \mathrm{~g})$ were extracted successively with solvents in the following order: hexane, chloroform, and ethyl acetate by maceration for $24 \mathrm{~h}$ at $25^{\circ} \mathrm{C}$. The collected three extracts were filtered and evaporated to dryness by removing the solvents under a vacuum on a rotary evaporator (Figure 1). Then these three extracts were dissolved in methanol, and their antioxidant and antimicrobial activities were tested.

For fructan extraction, the residual plant material after drying was extracted with distilled water (at a solid to solvent ratio of 1:10 w/v) in duplicate using a microwave device (Daewoo KOR, with microwave power $700 \mathrm{~W}$ and frequency of $2450 \mathrm{MHz}$ ) for $5 \mathrm{mins}$ duration of each extraction. The cooled filtrate was precipitated with $95 \%$ ethanol $(1: 4 \mathrm{v} / \mathrm{v})$. The precipitate was separated by centrifugation and then purified by recrystallization of boiling water and precipitated with acetone $(1: 5 \mathrm{v} / \mathrm{v})$. The resulting polysaccharide was filtrated and dried under a vacuum (Figure 1).

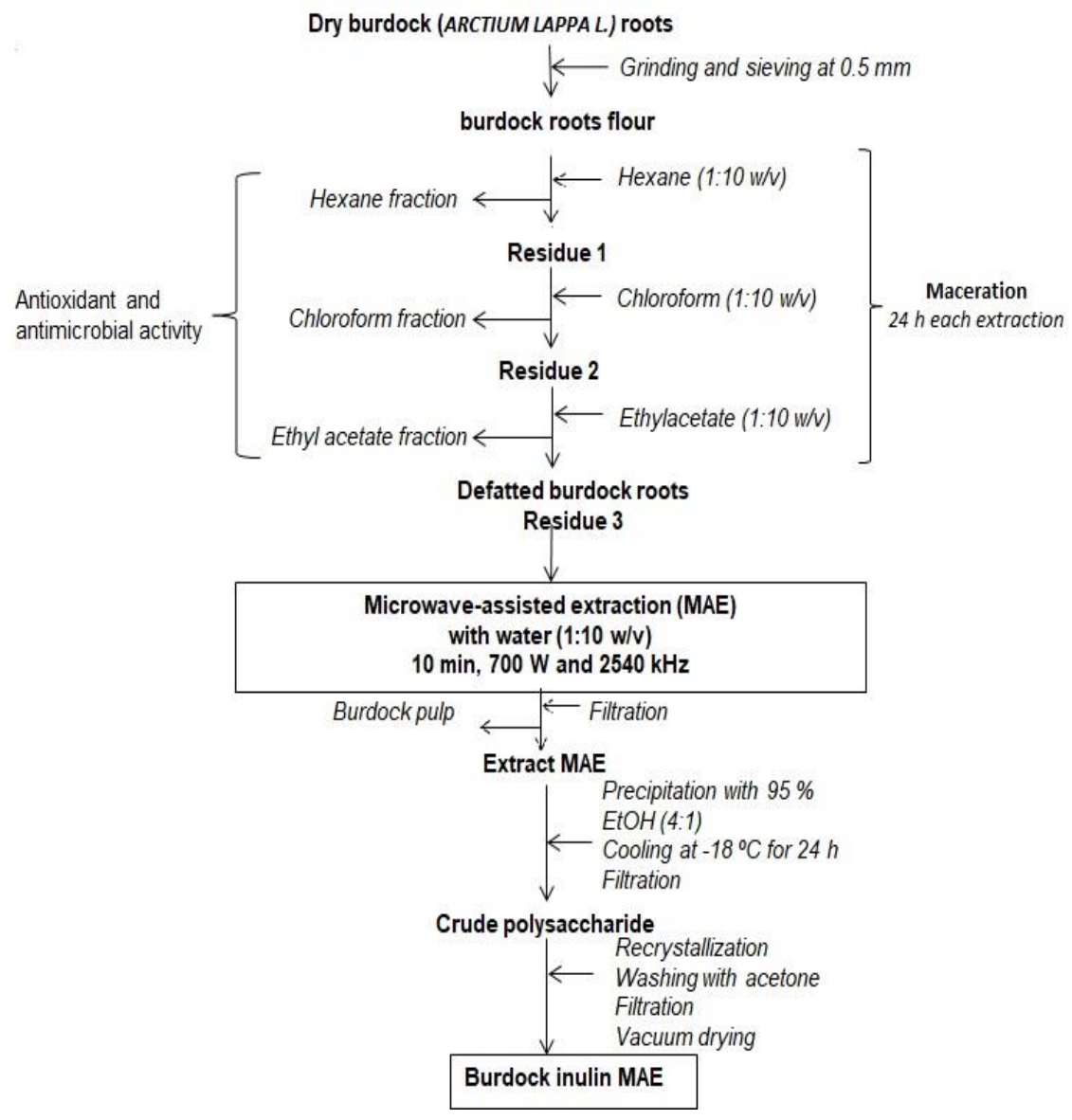

Figure 1. Sequential solvent extraction of Arctium lappa L. roots.

\subsection{Total phenols.}

The total phenolic content (TPC) was evaluated by the Folin-Ciocalteu's reagent [30]. Burdock root extract $(200 \mu \mathrm{L})$ was mixed with $1 \mathrm{ml}$ Folin-Ciocalteu reagent diluted five times and then $800 \mu \mathrm{L} 7.5 \% \mathrm{Na}_{2} \mathrm{CO}_{3}$ was added to the mixture. The sample absorbance was read at 
$765 \mathrm{~nm}$ after 20 min against a blank. The data were shown in mg equivalent of gallic acid (GAE) g/dry extract.

\subsection{Total dihydroxycinnamic derivative (DCA).}

The total dihydroxycinnamic acid (including caffeoyl derivatives) content was expressed as chlorogenic acid derivates per $g$ extract [31].

\subsection{Total flavonoids.}

$\mathrm{Al}\left(\mathrm{NO}_{3}\right)_{3}$ reagent were used for estimation of the total flavonoids. The sample was read at $415 \mathrm{~nm}$. The data were expressed as $\mathrm{mg}$ equivalents quercetin (QE) per $\mathrm{g}$ extract according to the quercetin calibration curve [32].

\subsection{HPLC analysis of terpenes and phenolic acids.}

Burdock extracts were dissolved in methanol. Analysis of triterpene was done on a Hitachi LaChrom Elite®HPLC System (Hitachi High Technologies America, Inc., Schaumburg, Illinois, USA), with diode-array detector (DAD, L-2455) and EZChrom Elite ${ }^{\mathrm{TM}_{\mathrm{S}}}$ sftware. The separation of oleanolic was performed on a reverse-phase column Supelco, Discovery ${ }^{\circledR} \mathrm{HS} \mathrm{C} 18(5 \mu \mathrm{m}, 25 \mathrm{~cm} \times 4.6 \mathrm{~mm})$ at $26^{\circ} \mathrm{C}$ with mobile phase methanol:0.1\% $\mathrm{HCOOH}=92: 8(\mathrm{v} / \mathrm{v})$ at a flow rate of $0.4 \mathrm{~mL} / \mathrm{min}$ in an isocratic operation mode [33]. HPLC analysis of phenolic acids was performed as previously described [34] using the same apparatus and column, operated at $30^{\circ} \mathrm{C}$ with gradient mode with mobile phase consist of $2 \%(\mathrm{v} / \mathrm{v})$ acetic acid (solvent A) and acetonitrile (solvent B) and the flow rate was $0.8 \mathrm{~mL} / \mathrm{min}$. The detection was performed at 280 and $320 \mathrm{~nm}$,. The results were presented as $\mathrm{mg}$ of the respective phenolic acid per g extract [34].

\subsection{Antioxidant activity.}

DPPH (2,2-diphenyl-1-picryl-hydrazyl-hydrate) free radical method and ferric reducing antioxidant power (FRAP) method were used to evaluate antioxidant activity.

\subsubsection{DPPH method.}

For DPPH method, burdock extract $(150 \mu \mathrm{L})$ was added to $2.85 \mathrm{ml} 0.1 \mathrm{mM} \mathrm{DPPH}$ dissolved in methanol. The absorption was measured after $15 \mathrm{~min}$ at $37{ }^{\circ} \mathrm{C}$ at $517 \mathrm{~nm}$ in comparison to the blank containing methanol, and \% inhibition was calculated [32].

\subsubsection{FRAP method.}

The FRAP method was performed with some modifications [35]. The sample extract $(100 \mu \mathrm{L})$ was added to $3.0 \mathrm{ml}$ FRAP reagent. After $10 \mathrm{~min}$ at $37^{\circ} \mathrm{C}$ in darkness, the absorbance was measured at $593 \mathrm{~nm}$ against a blank. Antioxidant activity was expressed as mM Trolox ${ }^{\circledR}$ equivalents (TE) per g extract [32].

\subsection{Antimicrobial activity.}

The agar well diffusion method was used for the antimicrobial activity [36]. The selected microorganisms from the collection of the Department of Microbiology at the University of Food Technologies, Plovdiv, Bulgaria, were used: Gram-positive (Listeria 
monocytogenes, Staphylococcus aureus ATCC 25923, and Bacillus cereus 52/GI1), Gramnegative (Salmonella sp., Escherichia coli ATCC 8739, Pseudomonas aeruginosa ATCC 9027 and Proteus vulgaris), and yeast Candida albicans. The test bacteria (except of Bacillus cereus 52/GI1) and yeasts were cultured on Luria-Bertani agar medium supplemented with glucose (LBG agar) at $37^{\circ} \mathrm{C}$ for 24 hours as previously described [37]. B. cereus 52/GI1 was cultured on $\mathrm{LBG}$ agar medium at $30^{\circ} \mathrm{C}$ for 24 hours.

Minimal inhibitory concentration (MIC) of hexane, chloroform, and ethyl acetate burdock extracts was determined by a series of twofold dilutions of the extract, ranging from 10 to $0.079 \mathrm{mg} / \mathrm{mL}$ were prepared. The samples were pipetted in the quantity of $50 \mu \mathrm{L}$ per well in a preliminary inoculated with the test microorganisms LBG agar media. The Petri dishes were incubated at the above-mentioned conditions. The MIC values were evaluated as the lowest concentration of the extract that completely inhibited the growth of tested microorganisms around the agar well [36].

The MIC values evaluated as $\mathrm{mg} / \mathrm{mL}$ were recalculated and expressed as $\mathrm{mg} / 50 \mu \mathrm{L}$ (quantity of the extract in the agar wells). Ampicillin $(10 \mu \mathrm{g} / \mathrm{ml})$, Kanamycin $(6 \mathrm{mg} / \mathrm{ml})$, Streptomycin $(6 \mathrm{mg} / \mathrm{ml})$, and Penicillin $(1.2 \mathrm{mg} / \mathrm{ml})$ were used as standards, while only for Candida albicans Nystatin $(40 \mu \mathrm{g} / \mathrm{ml})$ was applied.

\subsection{Total fructans and HPLC-RID analysis of inulin and sugars in water extract.}

The water extraction was performed as previously described procedure [20]. The fructans content in water burdock extracts was determined by spectrophotometer using resorcinol-thiourea reagent at $480 \mathrm{~nm}$ [38]. Inulin and sugars were analyzed on an HPLC instrument Elite Chrome Hitachi (Japan), coupled with refractive index detector (RID) Chromaster 5450. The separation was performed with mobile phase distilled $\mathrm{H}_{2} \mathrm{O}$ on a column Shodex ${ }^{\circledR}$ Sugar SP0810 (300 mm $\times 8.0 \mathrm{~mm}$ i.d. $)$ with a guard column operating at $85^{\circ} \mathrm{C}$ with a flow rate $1.0 \mathrm{ml} / \mathrm{min}$.

\subsection{Characterization of isolated fructan.}

\subsubsection{Physicochemical characterization}

The melting point of isolated inulin was measured with a melting point apparatus Kofler apparatus, coupled with a camera. The reducing groups were determined by the PAHBAH method at $410 \mathrm{~nm}$ [39], while total fructose content by resorcinol-thiourea reagent at $480 \mathrm{~nm}$ [38]. The purity of burdock inulin was analyzed by HPLC instrument Elite Chrome Hitachi with a Shodex ${ }^{\circledR}$ Sugar SP0810 $(300 \mathrm{~mm} \times 8.0 \mathrm{~mm}$ i.d. $)$ at $85^{\circ} \mathrm{C}$, a flow rate $1.0 \mathrm{ml} / \mathrm{min}$ and the injection volume $20 \mu 1$ [40].

\subsubsection{Homogeneity and molecular weight .}

High-performance size-exclusion chromatography (HPLC-SEC) was used for the determination of number average molecular weight $(\mathrm{Mn})$, and weight average molecular weight (Mw) was used. Analysis of burdock inulin was performed on HPLC chromatograph ELITE LaChrome (VWR Hitachi, Japan) on a column Shodex OH-pack 806 M (ID 8mm and length $300 \mathrm{~mm}$ ), (Shodex Co., Tokyo, Japan) at $30^{\circ} \mathrm{C}$ and a RI detector (VWR Hitachi Chromaster, 5450, Japan) with $0.1 \mathrm{M} \mathrm{NaNO}_{3}$ [41]. Polydispersity index (X) of inulin was calculated as the ratio of the two molecular weights $\left(\mathrm{M}_{\mathrm{w}} / \mathrm{M}_{\mathrm{n}}\right)$. 
2.11.3. Fourier transformation infrared spectroscopy (FT-IR) spectroscopy.

Burdock inulin (2 mg) was pressed into KBr tablets. The FTIR spectrum was collected on a Nicolet FTIR Avatar Nicolet (Thermo Scientific, USA) spectrometer in the wavelength range of $4000-400 \mathrm{~cm}^{-1}$ after $132 \mathrm{scans}$ at a resolution of $2 \mathrm{~cm}^{-1}$.

2.11.4. NMR spectroscopy.

${ }^{13} \mathrm{C}$ NMR spectra were recorded using a Bruker AVIII $500 \mathrm{MHz}$ spectrometer operating at a frequency of $126 \mathrm{MHz}$, respectively. Inulin sample was dissolved in $99.95 \% \mathrm{D}_{2} \mathrm{O}(25$ $\mathrm{mg} / 0.6 \mathrm{ml})$.

\subsection{Functional properties of burdock inulin.}

Swelling properties of isolated inulin were evaluated as previously described [42]. The water-holding and oil-holding capacities of burdock inulin were evaluated [42,43]. Briefly, inulin $(100 \mathrm{mg}$ ) was added to the preweighed $50 \mathrm{ml}$ polypropylene centrifuge tubes and $10 \mathrm{ml}$ deionized water or sunflower oil was added, respectively. After $24 \mathrm{~h}$ at $20^{\circ} \mathrm{C}$ the samples were centrifuged at $3500 \mathrm{rpm}$ for $15 \mathrm{~min}$. The excess of water and oil was removed. The tubes were then weighed and dried at $105^{\circ} \mathrm{C}$ to constant weight.

\subsection{Statistical analysis.}

All analyses were performed in triplicate $(n=3)$ and replicated at least twice. Statistical analysis was performed by analysis of variance using STATISTICA 5.5 (Stat Soft Inc, Tulsa, OK, and USA) software and a probability value of $\mathrm{p} \leq 0.05$ was considered to denote a statistical significance difference.

\section{Results and Discussion}

\subsection{Bioactive compounds and antioxidant activity in burdock fractions.}

In our study, the initial moisture content in dry burdock roots was $12.9 \pm 0.2 \%$. The results for yield and phytochemical composition of three burdock root extracts were summarized in Table 1 . The highest yield was detected in hexane fraction $3.5 \pm 0.2 \%$. Only in this extract were triterpenes found, especially oleanolic acid $-268.2 \mathrm{mg} / \mathrm{g}$ dry extract. As a nonpolar solvent, it dissolves mainly lipophilic molecules. However, the hexane extract demonstrated the lowest levels of total phenolic compounds and the radical scavenging activity evaluated by the DPPH method due to the lowest phenols. The lowest extraction yield had chloroform extract $1 \%$, which also contained not only total phenols but also and total flavonoids (Table 1), as well. However, any phenolic acids were not detected in it. This could explain the highest antioxidant activity of this fraction comparing to the hexane fraction. In general, the highest value of bioactive phenolic compounds was detected in the third subsequent fraction obtained by ethyl acetate.

Ethyl acetate fraction did not contain triterpenes (oleanolic and ursolic acids), but it was rich in phenolic compounds. The level of total phenols and total flavonoids were the highest among this analyzed burdock root fraction - 45.5 $\pm 0.5 \mathrm{mg} \mathrm{GAE} / \mathrm{g}$ extract and 7.9 QE/g dry extract, respectively. Similar results for total phenols in burdock extract were reported by Horng et al. (2013), who found the content of $48.4 \pm 5.6 \mathrm{mg} / \mathrm{g}$ (mg gallic acid/g extract) [44]. 
The content of flavonoids in burdock roots varied in the range from 4.31 to $7.74 \mathrm{mg} \mathrm{QE} / \mathrm{g} \mathrm{dw}$ [20].

Table 1. Terpenes, phenolic compounds, phenolic acids, and antioxidant activity per g dry burdock extracts.

\begin{tabular}{|c|c|c|c|}
\hline \multirow[t]{2}{*}{ Phytocomponents } & \multicolumn{3}{|c|}{ Extracts } \\
\hline & Hexane & Chloroform & Ethyl acetate \\
\hline Yield, \% & $3.5 \pm 0.2^{\mathrm{b}}$ & $1.0 \pm 0.1^{\mathrm{a}}$ & $1.5 \pm 0.2^{\mathrm{b}}$ \\
\hline \multicolumn{4}{|l|}{ Terpenes, $\mathrm{mg} / \mathrm{g}$} \\
\hline Oleanolic acid & $268.2 \pm 0.5^{\mathrm{a}}$ & absent & absent \\
\hline \multicolumn{4}{|l|}{ Phenolic acids, mg/g } \\
\hline Chlorogenic acid & absent & absent & $5.0 \pm 0.2$ \\
\hline Caffeic acid & absent & absent & $0.4 \pm 0.1$ \\
\hline p-Coumaric acid & absent & absent & $2.1 \pm 0.2$ \\
\hline Cinnamic acid & absent & absent & traces \\
\hline Gallic acid & absent & absent & traces \\
\hline Total phenolic acids & absent & absent & $7.5 \pm 0.2$ \\
\hline Total phenols, mg GAE/g extract & $5.1 \pm 0.1^{\mathrm{a}}$ & $9.4 \pm 0.2^{b}$ & $45.5 \pm 0.5^{\mathrm{c}}$ \\
\hline TDCA, mg CE/g & absent & absent & $34.9 \pm 0.5$ \\
\hline Total flavonoids, mg QE/g extract & absent & $3.5 \pm 0.1$ & $7.9 \pm 0.3$ \\
\hline \multicolumn{4}{|c|}{ Antioxidant activity, $\mathrm{mM}$ Trolox/g extract } \\
\hline DPPH & $8.9 \pm 0.1^{\mathrm{a}}$ & $41.1 \pm 0.3^{\mathrm{b}}$ & $308.3 \pm 6.1^{\mathrm{c}}$ \\
\hline FRAP & absent & absent & $169.5 \pm 0.5$ \\
\hline
\end{tabular}

Values are mean \pm standard deviation. Different letters within each column indicate significant differences according to Tukey's test at $\mathrm{p}<0.05$.

It was reported that burdock roots contain chlorogenic acids, ester of caffeic acid, and quinic acid [6]. In our case, five phenolic acids (chlorogenic, caffeic, p-coumaric, cinnamic, and gallic were detected, as chlorogenic acid was in the highest amount $-5 \mathrm{mg} / \mathrm{g}$ extract. Due to the high content of chlorogenic acids, roots possessed a bitter and astringent taste [1]. Phenolic constituents as caffeic acid and chlorogenic acid possess a strong inhibitory effect on herpes virus (HSV-1, HSV-2) and adenovirus (ADV-3, ADV-11) [3]. It was published that among phenolic compounds, the chlorogenic acids were with the highest nutritional value in the burdock roots [17]. Literature data also showed that burdock roots contain caffeic acid derivates (chlorogenic acid, caffeic acid, cynarin), quercetin [6].

Caffeoylquinic acid derivatives were one of the main active ingredients of burdock roots, such as 1,3-, 1,4-, 1,5-dicaffeoylquinic acids [45] and possessed antiulcer activity [46] and neuroprotective effects [14]. In this study, the level of TDCA was $34.9 \mathrm{mg} / \mathrm{g}$ extract, which is $76 \%$ of the total phenolic content detected in the burdock ethyl acetate fraction. The highest antioxidant activity by DPPH method was evaluated in ethyl acetate burdock fraction - 309 $\mathrm{mM}$ TE/g extract. Moreover, this extract also demonstrated metal-reducing activity evaluated by FRAP method.

The better antioxidant potential of ethyl acetate fraction could be explained by the high content of phenolic compounds in it. An increase in the antioxidant capacity was observed with the increase in the number of caffeoyl units [17], especially on the quinic ring [14].

\subsection{Antimicrobial activity.}

Three sequential fractions (hexane, chloroform, and ethyl acetate) were tested for antimicrobial activity against Salmonella sp., Escherichia coli ATCC 8739, Listeria monocytogenes, Pseudomonas aeruginosa ATCC 9027, Proteus vulgaris, Staphylococcus aureus ATCC 25923, Bacillus cereus 52/GI1 and Candida albicans (Table 2). 
Table 2. Antimicrobial properties of root extracts from Arcticum lappa L. (MIC, mg/ml). Microorganisms

\begin{tabular}{|c|c|c|c|c|c|c|c|c|}
\hline \multirow[t]{2}{*}{ Microorganisms } & \multicolumn{3}{|c|}{ Extract } & \multirow[t]{2}{*}{ Amp } & \multirow[t]{2}{*}{ Kan } & \multirow[t]{2}{*}{ Str } & \multirow[t]{2}{*}{ Pen } & \multirow[t]{2}{*}{ Nys } \\
\hline & Hexane & Chloroform & $\begin{array}{c}\text { Ethyl } \\
\text { acetate }\end{array}$ & & & & & \\
\hline Salmonella sp. & $>10$ & $>10$ & 5 & 28 & 20 & 15 & 25 & na \\
\hline E. coli & $>10$ & $>10$ & 5 & 30 & 20 & 20 & 24 & na \\
\hline L. monocytogenes & $>10$ & $>10$ & $>10$ & 32 & 27 & 27 & 30 & na \\
\hline $\mathrm{P}$. aeruginosa & $>10$ & $>10$ & 0.16 & - & 17 & 32 & - & na \\
\hline P. vulgaris & $>10$ & $>10$ & 1.25 & - & 22 & 22 & 13 & na \\
\hline S. aureus & $>10$ & $>10$ & $>10$ & 32 & 25 & 23 & 28 & na \\
\hline B. cereus & $>10$ & $>10$ & 0.31 & 28 & 30 & 30 & 20 & na \\
\hline C. albicans* & $>10$ & $>10$ & 2.5 & na & na & na & na & 13 \\
\hline
\end{tabular}

Legend: Extracts from Arcticum lappa L. where: controls: Amp - Ampicillin (10 $\mu \mathrm{g} / \mathrm{ml})$; Kan - Kanamycin (6 $\mathrm{mg} / \mathrm{ml}) ; \mathrm{Str}$ - Streptomycin $(6 \mathrm{mg} / \mathrm{ml})$; Pen - Penicillin $(1.2 \mathrm{mg} / \mathrm{ml}),{ }^{*}$ Nystatin $(40 \mu \mathrm{g} / \mathrm{ml})$ - only for Candida albicans. na - not applied.

In general, the tested burdock fractions showed better antimicrobial activity in comparison to the used antibiotic controls Ampicillin $(10 \mu \mathrm{g} / \mathrm{ml})$, Kanamycin $(6 \mathrm{mg} / \mathrm{ml})$, Streptomycin $(6 \mathrm{mg} / \mathrm{ml})$, and Penicillin $(1.2 \mathrm{mg} / \mathrm{ml})$. Hexane and ethyl acetate fractions showed antimicrobial activity against all eight microorganisms in the concentrations of the extract below $10 \mathrm{mg} / \mathrm{ml}$. However, the ethyl acetate burdock fraction demonstrated the highest activity in comparison to the other two fractions. The lowest minimum inhibitory concentration below $1 \mathrm{mg} / \mathrm{ml}$ demonstrated ethyl acetate fraction from burdock against $P$ s. aeruginosa and Bacillus cereus 52/GI1. The lower MIC of ethyl acetate and better antimicrobial activity could be explained with detected phenolic acids - chlorogenic and caffeic acids.

In other research, it was reported that crude $70 \%$ ethanol extract of A. lappa showed in vitro antimicrobial activity against some Gram-positive and Gram-negative pathogenic bacteria, such as $P$. aeruginosa, S. aureus, Salmonella typhimurium, E.coli, Listeria monocytogenes, Streptococcus pyogenes, Brucella abortus, and Bacillus anthracis in concentration $(50-100 \mathrm{mg} / \mathrm{ml})$ higher than that in our study [47]. It was also reported that the volatile constituents of roots exhibited moderate antimicrobial activity against bacteria (Escherichia coli and Bacillus subtillis) and significant antifungal activity (Candida albicans and Aspergillus niger ferm-Bam C-21) [48]. The antimicrobial activity hydroalcoholic extract of burdock roots was tested by the serial dilution method against bacterial strains (Staphylococcus aureus ATCC 6538, Escherichia coli ATCC 8739, and Salmonella abony NCTC 6017) [49]. Moreover, Gentil et al. (2006) demonstrated that ethyl acetate fraction $A$. appa was used effectively as an intracanal medication for 5 days in teeth infected with $C$. albicans, E. coli, L. acidophilus, P. aeruginosa [50]. Therefore, the current research enriched the information about the antimicrobial potential of ethyl acetate, as parallel with it revealed the antimicrobial activity of the other two fractions.

\subsection{Carbohydrate composition of water fraction.}

Carbohydrate content detected in water extract from burdock roots was shown in Table 3. The carbohydrates - inulin, fructooligosaccharides (nystose and 1-kestose), sugars (sucrose, glucose, and fructose) were found (Figure 2).

Table 3. Fructan and sugar content in Arcticum lappa L roots, g/100 g dry weight.

\begin{tabular}{l|l|l|l|l|l|l|l} 
Compounds & $\begin{array}{l}\text { Total } \\
\text { fructans }\end{array}$ & Inulin & Nystose & 1-Kestose & Sucrose & Glucose & Fructose \\
\hline Value & $9.0 \pm 2.2$ & $7.3 \pm 0.1$ & $0.2 \pm 0.1$ & $0.1 \pm 0.0$ & $0.5 \pm 0.1$ & $0.7 \pm 0.1$ & $0.8 \pm 0.2$
\end{tabular}




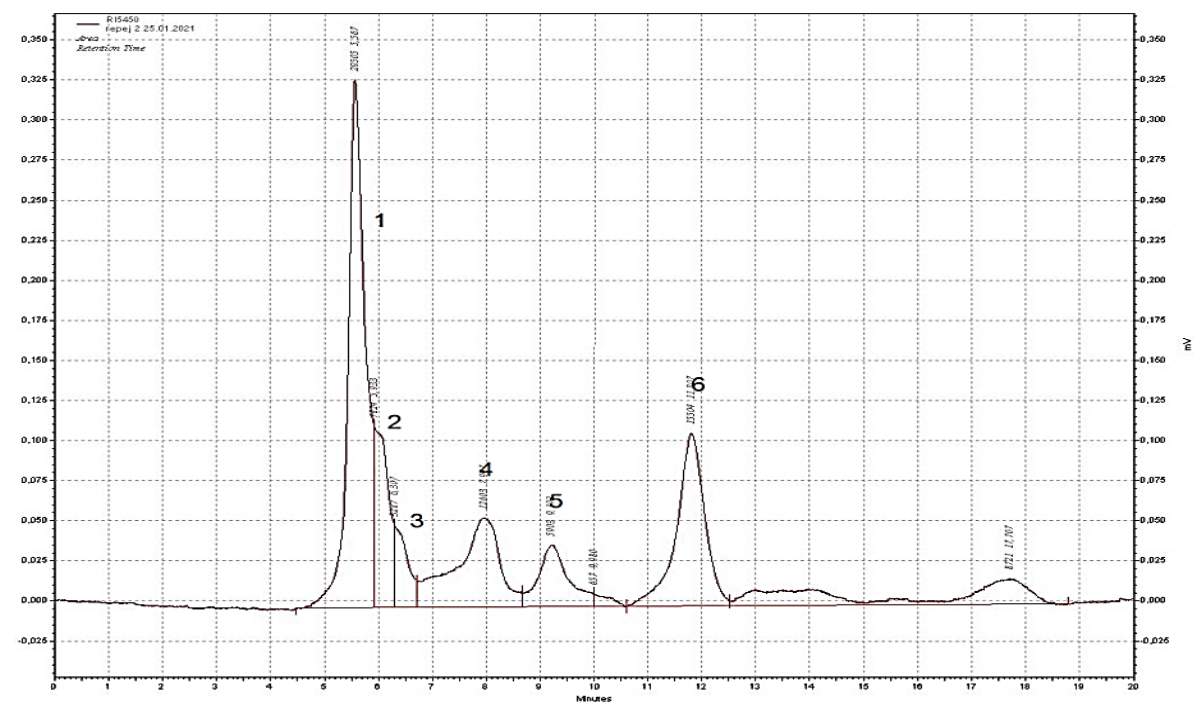

Figure 2. HPLC-RID chromatograms of water extract from Arcticum lappa L. after sequential solvent extraction where: 1 - inulin, 2 - nystose, 3 -1-kestose, 4 - sucrose, 5 - glucose, and 6 - fructose

The total fructan content was $9.0 \pm 2.2 \mathrm{~g} / 100 \mathrm{~g}$ dry weight, as $80 \%$ of the fructan content was represented by inulin $-7.3 \%$ (Table 3 ). 1-kestose and nystose content in this extract did not exceed $0.2 \mathrm{~g} / 100 \mathrm{~g}$. The detected results were 1-kestose and nystose, which are degraded compounds of fructan, were reported at concentrations of $8.82 \pm 0.99 \mathrm{mg} / \mathrm{g}(0.88 \%, \mathrm{w} / \mathrm{w})$ and $14.07 \pm 0.32 \mathrm{mg} / \mathrm{g}(1.41 \%, \mathrm{w} / \mathrm{w})$ [51]. Similar results were reported for nystose and 1-kestose in other research using different extraction approaches [20].

Among fructooligosaccharide only nystose and 1-kestose was detected in a small amount. In most of the studies, inulin content in the burdock roots collected from Bulgaria (2$5 \%$ ) $[4,20]$ was lower compared to Russian representatives (inulin content up to 30\%) [52] and the results from Iranian burdock 24-12\% [28]. Inulin content in burdock roots varied between 12 and $17 \%$ in the fresh root (or 50-70\% dried weight) or even of 3.6\% of fresh material [53]. Ren et al. found inulin content $174.33 \pm 3.68 \mathrm{mg} / \mathrm{g}$ in burdock root water extracts [16]. The variation of inulin and fructooligosaccharide content in burdock roots could be explained by cold climate conditions, geographical origin of burdock, harvest time, and storage conditions [54]. However, the results from this study demonstrated high inulin content $7 \%$ that were close to the date of burdock from Korea (9\% dw) [55] and other countries [56]. Therefore, the roots of burdock present a good inulin source, and further procedure for the isolation of fructan from inulin-type was performed by microwave-assisted extraction.

\subsection{Characteristics of isolated fructan.}

The isolated fructan was in lower yield $1.2 \%$ in comparison to other scientific studies $[7,18,22]$, where the typical yield was $4-5 \%$ (Table 4 ). This could be explained with applied microwave irradiation that could affect chain length and the physiological characteristics of raw material, climatic conditions, and harvest time. The physicochemical characteristics of isolated inulin were summarized in Table 4 . The burdock inulin presented white, brownish tasteless powder. The isolated substances contained $63 \%$ inulin calculated as fructose equivalent. Glucose content expressed as reducing groups was $3.5 \%$, lower than detected in dahlia inulin values [40]. 


\begin{tabular}{|c|c|c|c|}
\hline \multirow[t]{2}{*}{ Characteristics } & \multicolumn{3}{|c|}{ Inulin type fructan } \\
\hline & $\begin{array}{l}\text { Current } \\
\text { study }\end{array}$ & $\begin{array}{c}\text { linear } \beta 1,2- \\
\text { glucofructan }[22]\end{array}$ & $\begin{array}{c}\text { fructan from } A \text {. lappa } \mathrm{L} ., \\
\text { var. Herkules [18] }\end{array}$ \\
\hline Yield, \% & $1.2 \pm 0.3$ & $5.2 ; 14.2$ & 5.2 \\
\hline Purity, \% & $55.1 \pm 0.5$ & - & - \\
\hline Melting points, ${ }^{\circ} \mathrm{C}$ & $176-178$ & - & - \\
\hline Fructose content, $\%$ & $63.5 \pm 1.3$ & - & - \\
\hline Reducing groups, $\%$ & $3.5 \pm 0.5$ & glucose in traces & $5.0 \pm 0.2$ \\
\hline DPn by spectrophotometric method & 20 & - & - \\
\hline $\mathrm{Mm}, \mathrm{kDa}$ & 3.82 & $\begin{array}{c}2.95 \\
5.0-5.7\end{array}$ & $\begin{array}{c}2.95 \text { (cold water) } \\
4.85 \text { (hot water) }\end{array}$ \\
\hline $\mathrm{Mn}, \mathrm{kDa}$ & 3.70 & - & - \\
\hline DP by HPLC_SEC & 24 & $18-19$ & $14-15$ \\
\hline Polydispersity index & 1.03 & - & - \\
\hline Appearance & $\begin{array}{c}\text { White brownish } \\
\text { powder }\end{array}$ & $\begin{array}{c}\text { a white water soluble } \\
\text { powder }\end{array}$ & $7.5 \pm 0.2$ \\
\hline Swelling capacity, $\mathrm{ml} / \mathrm{g}$ & $8.0 \pm 0.3$ & - & - \\
\hline Water-holding capacity, g water/g & $4.3 \pm 0.4$ & - & - \\
\hline Oil-holding capacity, g oil/g & $6.7 \pm 0.3$ & - & - \\
\hline
\end{tabular}

- Data not available in literature

3.4.1. Purity, homogenisty and molecular weight of burdock inulin.

The purity of burdock inulin was evaluated by HPLC-RID analysis (Table 3). The presented chromatograms demonstrated the presence of a single peak (inulin purity 52\%), followed by tailing due to the presence of fructooligosaccharides fraction (Figure 3A). The retention time of the analyte $\left(\mathrm{R}_{\mathrm{t}}=5.85 \mathrm{mins}\right)$ coincided with the reference -chicory inulin $(\mathrm{DP}=22)$.
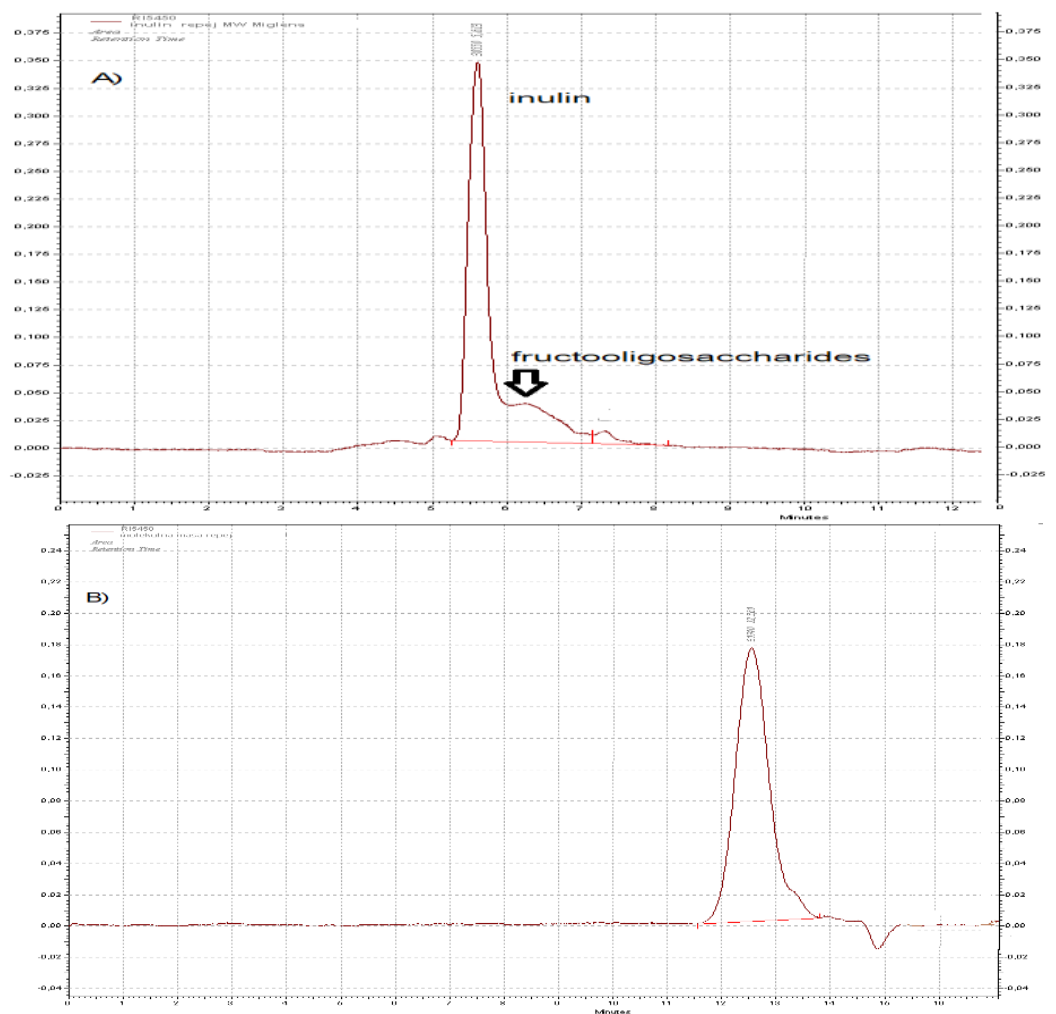

Figure 3. HPLC chromatograms of inulin form Arcticum lappa L., where A) HPLC-RID chromatogram for purity; B) HPLC-SEC chromatogram for homogenisity and molecular weight

The dominant polysaccharides component, separated by HPLC-SEC displayed a single and symmetrically sharp peak corresponding to $\mathrm{M}_{\mathrm{w}}=3.82 \mathrm{kDa}$ for inulin (Figure $3 \mathrm{~B}$ ). Similar homogeneity for burdock fructan was reported by Liu et al. [7], who obtained fraction with 
molecular weight $4600 \mathrm{Da}$ and yield $4.8 \%$ using precipitation with $95 \%$ ethanol. Water-soluble branched fructan (yield 4.4\%) from Arctium lappa roots with molecular weight $5.12 \times 10^{3} \mathrm{Da}$ was also isolated [26]. In our study molecular weights of inulin from burdock were presented in Table 4. Weight molecular weight (Mw) and number molecular weight (Mn) were evaluated using dextran as standards. The weight molecular weight was $3.82 \mathrm{kDa}$ that was near to obtained glucofructan from Arcticum lappa L. roots $2.9 \mathrm{kDa}$ obtained by some other authors $[18,22]$. The polydispersity of inulin from Arcticum lappa L. roots was 1.03 , which was near dahlia inulin [40].

\subsubsection{Functional properties.}

Until now, information about the functional properties of inulin from burdock roots is absent. Lou et al. [8] evaluated functional properties of burdock root by-product powder resulted after inulin extraction. This is the first detailed study that revealed the functional properties of burdock inulin. The swelling capacity of burdock inulin was $8.0 \mathrm{ml} / \mathrm{g} \mathrm{sample}$ (Table 4) was higher than the reported data for some inulin from plant sources. In comparison with inulin from chicory, salsify, agave, Jerusalem artichoke burdock inulin showed higher swelling and water holding capacities [57-59]. Pectin from A.lappa roots had a WHC of 6.95 $\pm 0.65 \mathrm{~g}$ water [25], which was near to WHC of inulin reported in our study $-4.3 \mathrm{~g}$ water/g sample. The oil-holding capacity of burdock inulin was higher than the water holding capacity. The determined oil holding capacity was $6.7 \mathrm{~g}$ oil/g sample, which was near to reported values of salsify inulin [57], and twice higher than the oil-holding capacity of chicory inulin $(3.5 \mathrm{~g}$ oil/g), agave inulin (3.3 oil g/g) [58] and six-time higher than Jerusalem artichoke inulin (1.02 $\mathrm{g} / \mathrm{g}$ ) [59]. These results revealed the possible application of inulin from burdock roots as a stabilizer in oils and/or lipid-soluble components in food technology and pharmacy. Moreover,WHC of dietary fiber could contribute to its anti-constipation effect [25].

\subsubsection{FTIR spectra of inulin from Arcticum lappa.}

FTIR spectra of inulin isolated from Arcticum lappa $\mathrm{L}$. by microwave irradiation is shown (Figure 4). The detailed assignment of wavelength was summarized in Table 5. The FTIR spectra contain typical bands for inuline type fructan that coincided with literature reports $[7,18,22,57]$.

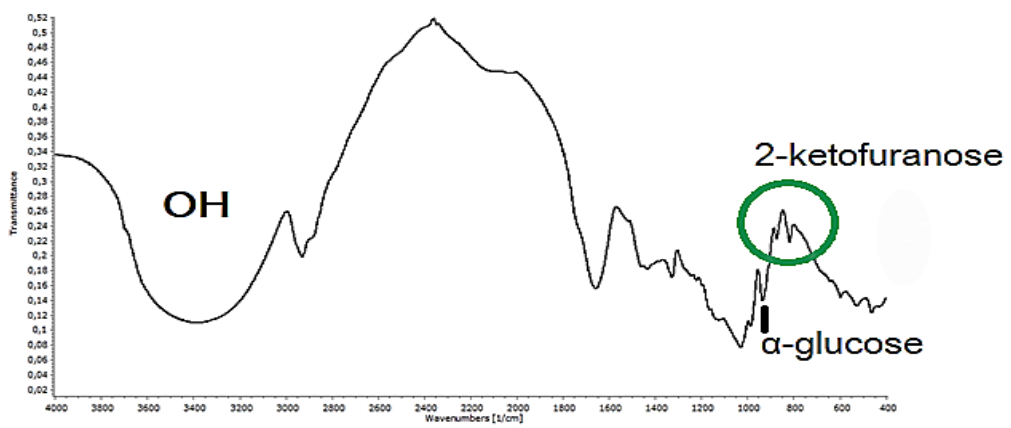

Figure 4. FTIR spectra of inulin from roots of Arcticum lappa L. obtained after microwave irradiation.

The broadband at $3330 \mathrm{~cm}^{-1}$ was assigned with free hydroxyl groups in inulin molecule. The band at $2933 \mathrm{~cm}^{-1}$ was due to $\mathrm{C}-\mathrm{H}$ stretching vibrations. The bands between 1160 and 990 $\mathrm{cm}^{-1}$ were due to $\mathrm{C}$-O stretching vibrations. The presence of $\alpha$-glucopyranosyl residue 
connected to fructofuranosyl units by $\alpha-1 \rightarrow 2$ bonds were clearly observed in the fingerprint region with typical bands at $934 \mathrm{~cm}^{-1}$.

Table 5. Assignment of characteristic bands of inulin from Arcticum lappa L. roots

\begin{tabular}{|c|c|c|}
\hline Wavelength, $\mathrm{cm}^{-1}$ & $\begin{array}{l}\text { Experimental } \\
\text { bands, } \mathbf{c m - 1}\end{array}$ & Assignment $[7,22,60,61]$ \\
\hline $3200-3400$ & 3330 & $\begin{array}{l}\mathrm{O}-\mathrm{H} \text { stretching vibrations, intra and inter hydrogen } \\
\text { bonds }\end{array}$ \\
\hline $2933-2981$ & 2929 & asymmetric stretching vibrations of $\mathrm{C}-\mathrm{H}$ from $\mathrm{CH}_{2}$ \\
\hline $2850-2904$ & 2889 & symmetric stretching vibrations of $\mathrm{C}-\mathrm{H}\left(\mathrm{CH}_{2}\right)$ \\
\hline $1664-1634$ & 1656 & absorption of water \\
\hline $1455-1470$ & 1433 & stretching vibration $\mathrm{C}-\mathrm{Hs}\left(\mathrm{CH}_{2}\right)$ in pyranosyl ring \\
\hline $1335-1336$ & 1326 & $\beta \mathrm{o}-\mathrm{H}(\mathrm{OH})$ \\
\hline $1125-1162$ & 1124 & stretching vibration $(\mathrm{C}-\mathrm{O}-\mathrm{C})$, glycoside linkage \\
\hline $1015-1060$ & 1029 & Stretching vibration $\mathrm{C}-\mathrm{O}$ \\
\hline $925-930 ; 935$ & 934 & $\alpha$-D-Glcp residue in chain \\
\hline 873 & 873 & $\begin{array}{l}\rho \mathrm{CH}_{2} \text { in ring, } \beta \text {-anomer bendings } \mathrm{C} 1-\mathrm{H} \text {, ring vibration } \\
\text { of (2-ketofuranose) }\end{array}$ \\
\hline 818 & 818 & 2-ketose in pyranosyl of furanosyl ring \\
\hline
\end{tabular}

Bands at 873 and $817 \mathrm{~cm}^{-1}$ in inulin spectra confirmed $\mathrm{CH}_{2}$ ring vibration of $\beta$-anomer and the structure of 2-ketofuranose. Similar bands for fructan from Arcticum lappa were reported [7].

\subsubsection{NMR spectra of burdock inulin.}

In ${ }^{13} \mathrm{C}$ NMR spectra of inulin, chemical shifts typical only for fructose units were observed (Figure 5): ${ }^{13} \mathrm{C}$ NMR $\left(126 \mathrm{MHz}, \mathrm{D}_{2} \mathrm{O}\right) \delta 103.28,81.06,76.77,74.28,61.99,60.96$ ppm. The spectra contained prominent shifts for C1-C6 carbons (C1 60.96 ppm, C2 103.28 ppm, C3 76.77 ppm, C4 74 ppm, C5 81 ppm, and C6 61.99 ppm) of fructosyl residue due to fructose repeated units. The ${ }^{13} \mathrm{C}$ shifts from glucose were not observed (Figure 5 ) due to the low quantity in the sample. Similar shifts in ${ }^{13} \mathrm{C}$ NMR spectrum were reported for fructans isolated from Arcticum lappa, which demonstrated the presence of linkage $\rightarrow 1)$-Fruf-( $\rightarrow$ and Fruf- $(2 \rightarrow[7,18,22,26]$.

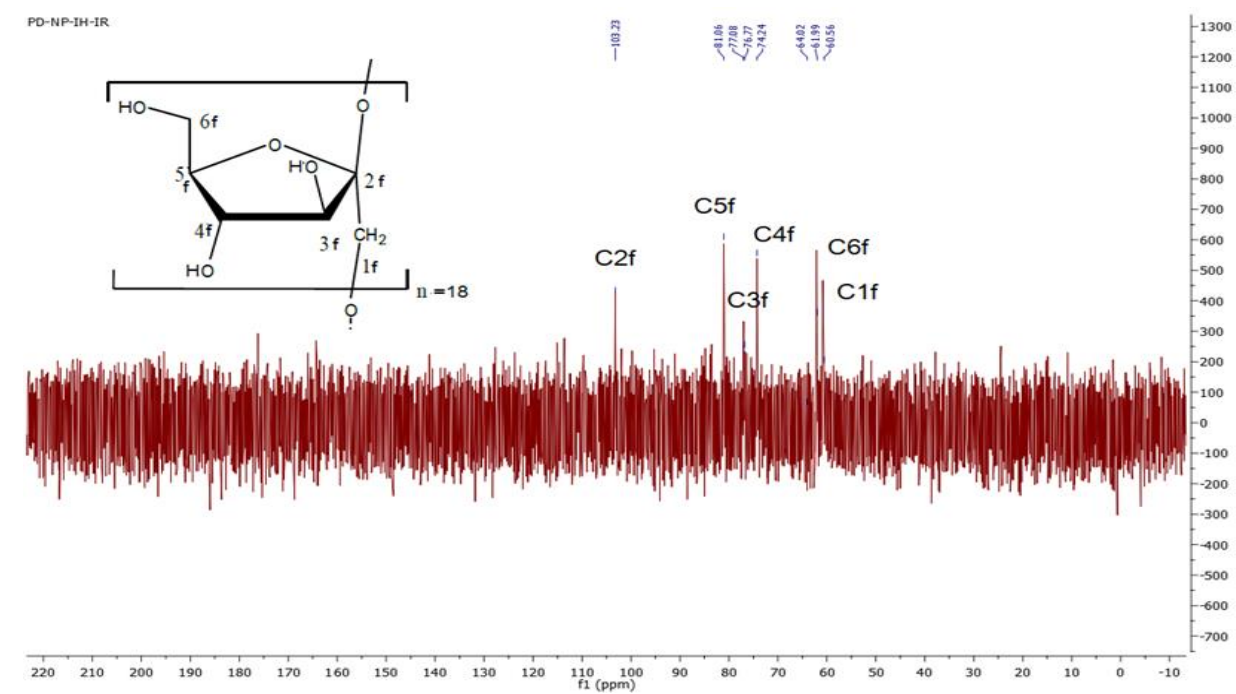

Figure 5. ${ }^{13} \mathrm{C}$ NMR spectra of inulin from roots of Arcticum lappa L. obtained after microwave irradiation.

The superposition of glucose shifts was observed in other studies and was reported for inulin from echinacea, dahlia, and stevia $[40,62,63]$. In the ${ }^{13} \mathrm{C}$ NMR spectra were observed only one shift at $103.28 \mathrm{ppm}$ corresponding to the fructose $\mathrm{C}-2$ carbon involved in $\beta-(2 \rightarrow 1)$ - 
D-fructofuranosylfructose bonds. Similar shifts at $103.2 \mathrm{ppm}$ were reported [26], but they also found branched fructan with a shift at $103.7 \mathrm{ppm}$ due to a $\beta$-(2,6)-linked fructosyl residue. In our case, we found linear fructan with typical $\beta-(2 \rightarrow 1)$-bonds. In DEPT 135 spectra (data were not shown) were identified methinic carbon atoms C5f, C3f, C4f as positive shifts. Two methylene carbon C6f and C1f appeared as negative shifts in DEPT 135 spectra, while the absence of anomeric carbons peaks in DEPT $135{ }^{13} \mathrm{C}$ NMR spectra of the polysaccharide indicated that quaternary carbon atoms existed in the compound.

\section{Conclusions}

The present study investigated the bioactive compounds in different fractions obtained from roots of Arcticum lappa L. The main detected components were oleanolic acid, chlorogenic acid, caffeic acid, $p$-coumaric acid, and inulin. The isolated polysaccharide from water fraction by microwave-assisted irradiation was characterized as inulin-type fructan with an average degree of polymerization 20-24, a molecular weight of $3.82 \mathrm{kDa}$. For the first time, functional properties of burdock inulin were demonstrated, as it demonstrated promising swelling properties and better oil-holding capacity. The results for antioxidant potential, antimicrobial activity, and phytocomponents are fundamental knowledge for applying this plant in medicinal cosmetics and as a functional ingredient in healthy foods enriched with fibers and antioxidants.

\section{Funding}

This research received no external funding.

\section{Acknowledgments}

We thank Nevena Petkova and Nikola Burdjiev (University "St. Kliment Ohridski”, Sofia, Bulgaria), who provided technical support for NMR studies.

\section{Conflicts of Interest}

The authors declare no conflict of interest.

\section{References}

1. Nabeshima, E.H.; Moro, Th.M.A.; Campelo, P.H.; Sant'Ana, A.S., Clerici, M.T.P.S. Tubers and roots as a source of prebiotic fibers. In Advances in Food and Nutrition Research, 2020, 94, 267-293, https://doi.org/10.1016/bs.afnr.2020.06.005.

2. Lee, S.; Moon, H.K.; Kim, I.D.; Shin D.H. Physicochemical characteristics of different parts of burdock. (Arctium sp.). Curr. Res. Agric. Life Sci. 2014; 32, 75-78, http://www.koreascience.or.kr/article/JAKO201424566319422.pdf.

3. Chan, Y.S.; Cheng, L.N.; Wu, J. H.; Chan, E.; Kwan, Y.W.; Lee, S. M. Y.; George, S.L.; Yu P.; Chan, S. W. A review of the pharmacological effects of Arctium lappa (burdock). Inflammopharmacology. 2011, 19, 245-254, http://dx.doi.org/10.1007/s10787-010-0062-4.

4. Petkova, N.; Ivanova, L.; Filova, G.; Ivanov, I.; Denev P. Antioxidants and carbohydrate content in infusions and microwave extracts from eight medicinal plants. J. Appl. Pharm. Sci. 2017, 7, 055-061, http://dx.doi.org/10.7324/JAPS.2017.71008.

5. Machado, F.B.; Yamamoto, R.E.; Zanoli, K.; Nocchi, S.R.; Novello, C.R.; Schuquel, I.T.A.; Sakuragui, C.M.; Luftmann H., Ueda-Nakamura, T.; Nakamura, C.V.; Palazzo de Mello J.C. Evaluation of the antiproliferative activity of the leaves from Arctium lappa by a bioassay-guided fractionation. Molecules. 2012, 17, 1852-1859, http://dx.doi.org/10.3390/molecules17021852. 
6. Ferracane, R.; Graziani, G.; Gallo, M.; Fogliano, V.; Ritieni V.. Metabolic profile of the bioactive compounds of burdock (Arctium lappa) seeds, roots and leaves. J. Pharm. Biomed. Anal. 2010, 51, 399404, http://dx.doi.org/10.1016/j.jpba.2009.03.018.

7. Liu, W.;Wang, J.; Zhang, Z.; Xu, J.; Xie, Z.; Slavin, M.; Gao, X. In vitro and in vivo antioxidant activity of a fructan from the roots of Arctium lappa L. Int. J. Biol. Macromol. 2014, 65, 446-453, http://dx.doi.org/10.1016/j.ijbiomac.2014.01.062.

8. Lou, Z.; Wang, H.; Wang, D.; Zhang Y. Preparation of inulin and phenols-rich dietary fibre powder from burdock root. Carbohydr. Polym. 2009, 78, 666-671, http://dx.doi.org/10.1016/j.carbpol.2009.05.029.

9. Miazga-Karska, M.; Michalak, K.; Ginalska, G. Anti-acne action of peptides isolated from burdock rootpreliminary studies and pilot testing. Molecules, 2020, 25, 2027, http://dx.doi.org/10.3390/molecules25092027.

10. Taleb Agha, M.; Baharetha, H.M.; Al-Mansoub M.A.; Tabana Y.M.; Kaz Abdul Aziz, N.H.; Yam M.F.; Abdul Majid, A.M.S. Proapoptotic and antiangiogenic activities of Arctium Lappa L. on breast cancer cell lines. Scientifica (Cairo). 2020, 2020, 7286053. http://dx.doi.org/10.1155/2020/7286053.

11. Skowronska, W.; Granica, S.; Dziedzic, M.; Kurkowiak, J.; Ziaja, M.; Bazylko, A. Arctium lappa and Arctium tomentosum, sources of Arctii radix: comparison of anti-lipoxygenase and antioxidant activity as well as the chemical composition of extracts from aerial parts and from roots. Plants. 2021, 10, 78, https://doi.org/10.3390/plants10010078.

12. Alsamarrai, Z.A.A.S.; Al-Samarrai, R.R.; Alsamarrai, A. Isolation and identification of flavonoids from Arctium lappa stem and study the hepatoprotective effect on acetaminophen induced liver damage. Int. J. Psychosoc. Rehabilitation. 2020, 24, https://doi.org/10.37200/IJPR/V24I5/PR2020226.

13. Wu K.C.; Weng, H.K.; Hsu, Y.S.; Huang P.J.; Wang, Y.K. Aqueous extract of Arctium lappa L. root (burdock) enhances chondrogenesis in human bone marrow-derived mesenchymal stem cells. BMC Complement Med. Ther. 2020, 20, 364, https://doi.org/10.1186/s12906-020-03158-1.

14. Gao, H.; Jiang, X.W.; Yang, Y.; Liu, W.W.; Xu, Z.H.; Zhao, Q.C. Isolation, structure elucidation and neuroprotective effects of caffeoylquinic acid derivatives from the roots of Arctium lappa L. Phytochemistry. 2020, 177, 112432, https://doi.org/10.1016/j.phytochem.2020.112432.

15. Ha, M.S.; Yook J.S.; Lee, M.; Suwabe, K., Jeong, W.M.; Kwak, J.J.; Soya H. Exercise training and burdock root (Arctium lappa L.) extract independently improve abdominal obesity and sex hormones in elderly women with metabolic syndrome. Sci. Rep. 2021, 11, 5175, https://doi.org/10.1038/s41598-021-84301-x .

16. Ren, G.Q.; Luan, X.N.; Dou, D.Q. Analysis of functional components of burdock (Arctium lappa root) standard water extract and its aphrodisiac effect in experimental rats. J. Chem. Soc. Pak. 2020, 42, 94-102, https://inis.iaea.org/search/search.aspx?orig_q=RN:51073678.

17. Moro, T.M.A.; Clerici, M.T.P.S. Burdock (Arctium lappa L.) roots as a source of inulin-type fructans and other bioactive compounds: current knowledge and future perspectives for food and non-food applications. Int. Food Res. J. 2020, 141, 109889, http://dx.doi.org/10.1016/j.foodres.2020.109889.

18. Kardošová, A.; Ebringerová, A.; Alföldi, J.; Nosál’ová, G.; Fraová, S.; Híbalová V. A biologically active fructan from the roots of Arctium lappa L., var. Herkules. Int J Biol Macromol. 2003, 33, 135-140, http://dx.doi.org/10.1016/s0141-8130(03)00079-5.

19. Jaiswal, R.; Kuhnert, N. Identification and characterization of five new classes of chlorogenic acids in burdock (Arctium lappa L.) roots by liquid chromatography/tandem mass spectrometry. Food Funct. 2011, 2, 63-71, https://doi.org/10.1039/c0fo00125b,

20. Petkova, N.; Ivanov, I.; Mihaylova, D.; Lante A. Effect of pressure liquid extraction and ultrasonic irradiation frequency on inulin, phenolic content and antioxidant activity in burdock (Arctium lappa L.) roots. Acta Sci. Pol.-Hortorum Cultus. 2020, 19, 125-133, https://doi.org/10.24326/asphc.2020.3.11.

21. Teixeira, R.S.; Carvalho, P.H.D.; Aguiar, J.A.K.; Medeiros, V.P.; Da Silva Filho, A.A.; Nascimento, J.W.L. Improved method for obtaining of arctigenin from $<\mathrm{i}>$ arctium lappa $</ \mathrm{i}>1$. and its antiproliferative effect on human hepatocarcinoma HEPG2 cells. Curr. Bioact. Compd., 2020, 16, 358, https://doi.org/10.2174/1573407214666181115124223.

22. Olennikov, D.N.; Tankhaeva, L.M. A quantitative assay for total fructans in burdock (Arctium spp.) roots. Russ. J. Bioorganic Chem. 2011, 37, 893-898, https://doi.org/10.1134/S1068162011070181.

23. Fuchigami, M.; Kishigami, Y.; Sasaki, A. Pectic polysaccharides in edible burdock root. J. Home Econom. Japan. 1990, 41, 957-963, https://doi.org/10.11428/jhej1987.41.957.

24. Zhang, X., Zhang, N., Kan, J., Sun, R., Tang, S., Wang, Z., Chen, M., Liu, J., Jin C. Anti-inflammatory activity of alkali-soluble polysaccharides from Arctium lappa L. and its effect on gut microbiota of mice 
with inflammation. Int. J Biol Macromol. 2020, 154, 773-787, https://doi.org/10.1016/j.ijbiomac.2020.03.111.

25. Li, K.; Zhu, L.; Li, H.; Zhu, Y.; Pan, C.; Gao, X.; Liu, W. Structural characterization and rheological properties of a pectin with anti-constipation activity from the roots of Arctium lappa L. Carbohydr. Polym. 2019, 215, 119-129, https://doi.org/10.1016/j.carbpol.2019.03.051.

26. Wang, Y.; Zhang, N.; Kan, J.; Zhang, X.; Wu, X.; Sun, R.; Tang, S.; Liu, J.; Qian, C.; Jin C. Structural characterization of water-soluble polysaccharide from Arctium lappa and its effects on colitis mice. Carbohydr. Polym, 2019, 213, 89-99, https://doi.org/10.1016/j.carbpol.2019.02.090.

27. Lei, S. A novel fructan possessing db value from roots of Arctium lappa L. Open Glycoscience. 2009, 2, 2527, https://doi.org/10.2174/1875398100902010025.

28. Milani, E.; Koocheki, A.; Golimovahhed Q.A. Extraction of inulin from burdock root (Arctium lappa) using high intensity ultrasound. Int. J. Food Sci. Technol. 2011, 46, 1699-1704, https://doi.org/10.1111/j.13652621.2011.02673.x.

29. AOAC 2007. International, Official methods of analysis, 18th edn. Gaithersburg, Maryland, US: AOAC International https://www.aoac.org/official-methods-of-analysis-21st-edition-2019/.

30. Stintzing, F.; Nerbach, K.; Mosshammer, M.; Carle, R.; Yi, W.; Sellappan, S.; Acoh, C.; Bunch, R.; Felker P. Color, betalain pattern, and antioxidant properties of cactus pear (Opuntia Spp.) clones. J. Agric. Food Chem. 2005, 53, 442-451, https://doi.org/10.1021/jf048751y.

31. Fraisse, D.; Felgines, C.; Texier, O.; Lamaison, J-L. Caffeoyl derivatives: Major antioxidant compounds of some wild herbs of the Asteraceae family. Food Nutr. Sci. 2011, 2, 181-192, https://doi.org/10.4236/fns.2011.23025.

32. Ivanov, I.G.; Vrancheva, R.Z.; Marchev, A.S.; Petkova, N.T.; Aneva, I.Y.; Denev, P.P.; Georgiev, V.G.; Pavlov A.I. Antioxidant activities and phenolic compounds in Bulgarian Fumaria species. Int J Curr Microbiol Appl Sci. 2014, 3, 296-306, https://www.semanticscholar.org/paper/Antioxidant-activities-andphenolic-compounds-in-Ivanov-Vrancheva/3be9df25ed8c217ed42ca21b00b7efbee45bbf14.

33. Vrancheva, R.; Ivanov, I.; Dincheva, I.; Badjakov, I.; Pavlov, A. Triterpenoids and other nonpolar compounds in leaves of wild and cultivated vaccinium species. Plants. 2021, 10, 94-99, https://doi.org/10.3390/plants10010094.

34. Terzieva, A. V.; Vrancheva, R. Z.; Delchev, N. D. Antioxidant activity of different extracts of dried and frozen fruits of Schisandra chinensis (Turcz.) Baill. Bulg. Chem. Commun. 2017, 49, 78-82, http://www.bcc.bas.bg/BCC_Volumes/Volume_49_Special_G_2017/BCC-49-G-Terzieva-78-82.pdf.

35. Benzie, F.; Srain J. Ferric reducing ability of plasma (FRAP) as a measure of "antioxidant power": The FRAP assay. Anal. Biochem. 1996, 239, 70-77, https://doi.org/10.1006/ABIO.1996.0292.

36. Ivanov I.G.; Vrancheva R.Z.; Petkova, N.T.; Tumbarski, Y.; Dincheva, I.N.; Badjakov, I.K. Phytochemical compounds of anise hyssop (Agastache foeniculum) and antibacterial, antioxidant, and acetylcholinesterase inhibitory properties of its essential oil. J. Appl. Pharm. Sci. 2019, 9, 72-78, https://doi.org/10.7324/JAPS.2019.90210.

37. Tumbarski, Y.; Yanakieva, V.; Denkova-Kostova, R.; Denkova Z. Isolation, Identification and comparison of some properties of Lactobacillus delbrueckii subsp. bulgaricus strains from traditional bulgarian and italian yogurts. Carpathian J. Food Sci. Technol. 2021, 13, 38-54, https://doi.org/10.34302/crpjfst/2021.13.1.4.

38. Petkova, N.; Sherova, G.; Denev, P. Characterization of inulin from dahlia tubers isolated by microwave and ultrasound-assisted extractions. Int. Food Res. J. 2018, 25, 1876-1884, https://www.researchgate.net/publication/328638980_Characterization_of_inulin_from_dahlia_tubers_isol ated_by_microwave_and_ultrasound-assisted_extractions.

39. Lever, M. A new reaction for colorimetric determination of carbohydrates. Anal. Biochem. 1972, 47, 273279, https://doi.org/10.1016/0003-2697(72)90301-6.

40. Petkova, N.; Vrancheva, R.; Denev, P.; Ivanov, I.; Pavlov, A. HPLC-RID method for determination of inulin $\begin{array}{lllll}\text { and } \quad \text { fructooligosacharides. } & \text { 2014, } & \text { 99-107, }\end{array}$ https://www.researchgate.net/publication/258519409_HPLC-

RID_method_for_determination_of_inulin_and_fructooligosaccharides.

41. Murdzheva, D.; Petkova, N.; Todorova, M.; Vasileva, I.; Ivanov I.; Denev P. Microwave-assisted synthesis of methyl esters of alginic acids as potential drug carrier. Int. J. Pharm. Clin. Res. 2016, 8, 1361-1368, https://www.researchgate.net/publication/309312063_Microwave-

Assisted_Synthesis_of_Methyl_Esters_of_Alginic_Acids_as_Potential_Drug_Carrier. 
42. Robertson, Fr.; Monredon, D.de; Dysseler, P.; Guillon, F.; Amado, R.; Thibault, J.-Fr. Hydration properties of dietary fibre and resistant starch: a European collaborative study. LWT - Food Sci. Technol. 2000, 33, 7279, https://doi.org/10.1006/fstl.1999.0595.

43. Holloway, W.D.; Greig, R. I. Water holding capacity of hemicelluloses from fruits, vegetables and wheat bran. J. Food Sci. 1984, 49(6), 1632-1633, https://doi.org/10.1111/j.1365-2621.1984.tb12867.x.

44. Horng, C.T.; Tsai, M.L.; Hsueh, C.W.; Hsu, S.Y.; Wang, H.Y.; Chen F.A. Antioxidant activity of Arctium lappa L. and its effect on biochemical parameters in exercised rats. Asian J. Chem. 2013, 25, 1970-1974, https://doi.org/10.14233/ajchem.2013.13271.

45. Zheng, Z.; Wang, X.; Liu, P.; Li, M.; Dong, H.; Qiao X. Semi-preparative separation of 10 caffeoylquinic acid derivatives using high speed counter-current chromatogaphy combined with semi-preparative hplc from the roots of burdock (Arctium lappa L.). Molecules, 2018, 23, 429, https://doi.org/10.3390/molecules23020429.

46. Carlotto, J.; da Silva L.M.; Dartora, N.; Maria-Ferreira, D.; Sabry, D. de A.; Filho, A.P.; de Paula-Werner, M.F.; Sassaki, G.L.; Gorin, P.A.; Iacomini, M.; Cipriani, T.R.; de Souza, L.M. Identification of a dicaffeoylquinic acid isomer from Arctium lappa with a potent antiulcer activity. Talanta. 2015, 135, 5057, https://doi.org/10.1016/j.talanta.2014.11.068.

47. Thikra M.; Zainab A.; Zghair R. The inhibitory Effect of crude extract of Arctium lappa on some pathogenic bacteria. MRVSA. $\quad \mathbf{2 0 1 5 ,}$ 4, 32-39, https://www.researchgate.net/publication/327955715_The_inhibitory_Effect_of_Crude_Extract_of_Arctiu m_lappa_on_some_pathogenic_bacteria.

48. Aboutab, E.A.; El-tantawy, M.E.; Shams M.M. Chemical composition and antimicrobial activity of volatile constituents from the roots, leaves and seeds of Arctium lappa L. (Asteraceae) grown in Egypt. Egypt Pharmaceut J. 2013, 12, 173-176, https://doi.org/10.4103/1687-4315.124036.

49. Ionescu, D.; Predan, G.; Rizea, G. D.; Mihele, D.; Dune, A.; Ivopol, G.; C. Ionita.. Antimicrobial activity of some hydroalcoholic extracts of artichoke (Cynara scolymus), burdock (Arctium lappa) and dandelion (Taraxacum officinale). Bulletin of the Transilvania University of Brasov. Forestry, Wood Industry, Agricultural Food Engineering. Series II, 2013, 6, https://www.semanticscholar.org/paper/ANTIMICROBIAL-ACTIVITY-OF-SOMEHYDROALCOHOLIC-OF-Ionescu-Predan/20f1dbc370439986e6b7119dd8a66839f7de7560.

50. Gentil, M.; Pereira, J.V.; Sousa, Y.T.; Pietro, R.; Neto M.D.S.; Vansan L.P.; Castro França, S. de. In vitro evaluation of the antibacterial activity of Arctium lappa as a phytotherapeutic agent used in intracanal dressings. Phytother Res. 2006, 20, 184-186, https://doi.org/10.1002/ptr.1829.

51. Lee, J.; Ha, S.J.; Park, J., Kim, Y.H., Lee, N.H., Kim Y.E., Hong Y.S., Song K.M. Arctium lappa root extract containing L-arginine prevents TNF- $\alpha$-induced early atherosclerosis in vitro and in vivo. Nutr. Res. 2020, 77, 85-96, https://doi.org/10.1016/j.nutres.2020.03.003.

52. Bagaoutdinova, I.; Fedoseyeva, P.; Okoneshnikova F. Fructose-containing carbohydrates in plants of different families. Localization and content. Chem. Comput. Simul. Butlerov Commun.2001, 2,13-16, http://blog.ub.ac.id/ikariana/files/2012/04/13-16.pdf.

53. Van Loo, J.; Coussement, P.; De Leenheer, L.; Hoebregs, H.; Smits G. On the presence of inulin and oligofructose as natural ingredients in the Western diet. Crit Rev Food Sci Nutr. 1995, 35, 525-552, https://doi.org/10.1080/10408399509527714.

54. Ishiguro, Y.; Onodera, S.; Benkebli, N.; Shiomi N. Variation of total FOS, total IOS, inulin and their relatedmetabolizing enzymes in burdock roots (Arctium lappa L.) stored under different temperatures. Postharvest Biol. Technol. 2010, 56, 232-238, https://doi.org/10.1016/j.posthar-vbio.2010.01.010.

55. Cao, T.L.; Yang, S.Y.; Song, K.B. Development of burdock root inulin/chitosan blend films containing oregano and thyme essential oils. Int J Mol Sci. 2018, 19, 131-143, https://doi.org/10.3390/ijms19010131.

56. Roberfroid, MB. Introducing inulin-type fructans. $\mathrm{Br} J$ Nutr. 2005, 93 Suppl 1, S13-25, https://doi.org/10.1079/bjn20041350.

57. Petkova, N. Characterization of inulin from black salsify (Scorzonera hispanica L.) for food and pharmaceutical purposes. Asian J. Pharm. Clin. Res. 2018, 11, 221-225, https://doi.org/10.22159/ajpcr.2018.v11i12.28262.

58. Bouaziz, M.A.; Rassaoui, R.; Besbes S. Chemical composition, functional properties, and effect of inulin from tunisian Agave americana L. leaves on textural qualities of pectin gel. J Chem. 2014, 1-11, https://doi.org/10.1155/2014/758697. 
59. Rashid, S.; Rakha, A.; Butt, M.S.; Asgher, M. Physicochemical and techno-functional characterization of inulin extracted from chicory roots and Jerusalem artichoke tubers and exploring their ability to replace the fat in cakes. Prog.Nutr. 2018, 20, 191-202, https://doi.org/10.23751/pn.v20i2-S.6527.

60. Heize, T.; Liebert, T.; Koshella A. Esterification of Polysaccharides. Springer Verlag; Berlin, Heidelberg, Germany, 2006; 5-39, https://doi.org/10.1007/b98412.

61. Tipson, RS. Infrared spectroscopy of carbohydrates. A Review of the Literature. Washington, DC: NBS Monograph 1968, 1-38, https://nvlpubs.nist.gov/nistpubs/Legacy/MONO/nbsmonograph110.pdf.

62. Lopes, S. M. S.; Krausova, G.; Rada, V.; Goncalves, J.E.; Goncalves, R.A.C.; de Oliveira A.J.B. Isolation and characterization of inulin with a high degree of polymerization from roots of Stevia rebaudiana (Bert.). Bertoni. Carbohydr. Res. 2015, 411, 15-21, https://doi.org/10.1016/j.carres.2015.03.018.

63. Wack, M.; Blaschek W. Determination of the structure and degree of polymerization of fructans from Echinacea purpurea roots. Carbohydr. Res. 2006, 341, 1147-1153, https://doi.org/10.1016/j.carres.2006.03.034. 